
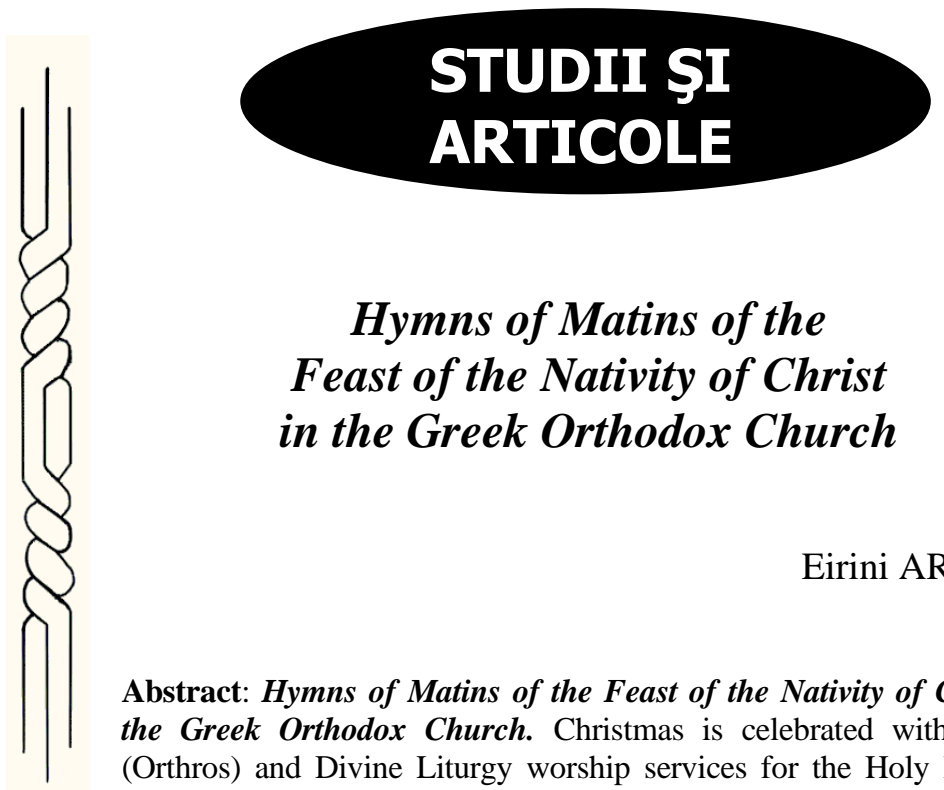

\title{
Hymns of Matins of the Feast of the Nativity of Christ in the Greek Orthodox Church
}

\section{Eirini ARTEMI*}

Abstract: Hymns of Matins of the Feast of the Nativity of Christ in the Greek Orthodox Church. Christmas is celebrated with Matins (Orthros) and Divine Liturgy worship services for the Holy Nativity. The Christmas hymnology is the fruit of the dogmatic theology of the Church. In this paper we will deal with only with the Hymns of Matins of the Feast of the Nativity of Christ. How do these hymns display and express the theology of the incarnation of the eternal living World? The theology of these hymns underlines that Holy Virgin Mary, the Theotokos, bore in a fleshly manner the Only-begotten Word of God made flesh (body and soul). These two natures, human and divine, were hypostatically united into the one personhood of Jesus Christ. This historic event is celebrated at Christmas feast. Without the incarnation of the Second Person of the Trinity, the Divine Logos, the redemption of the human race from the shackles of death and sin would be impossible. Christ forms a bridge between absolute infinite God and finite humanity. He is uniquely qualified to be the perfect mediator between God and man. His humanity resembles us in everything except sin, as he was sinless. These hymns express the original joyful excitement at the thought for God's appearance on earth as total man and remained total God.

\footnotetext{
* Dr. Eirini Artemi is adjunct professor in the Hellenic Open University in the postgraduate level in theology and professor in the Israel Institute of Biblical Languages of Hebrew University of Jerusalem. Also, she teaches Patristic Theology and Church History in the Orthodox Department of Theology School of the University of Kinshasa - Congo.
} 
Keywords: Christmas, Theanthropos, divine Liturgy, Orthos, Romanos the Melodist, Orthodox Greek Church

\section{Introduction}

The feast of Christmas is the celebration of the world's salvation through the Son of God who became man for our sake that, through him, we might ourselves become divine, sons of God the Father by the indwelling of his Holy Spirit in us. Despite the great importance of the feast of Christmas, Christians celebrated this with Epiphany in the one great feast of God's appearance on earth in the form of the human Messiah of Israel. The celebration of both of two feasts, Christmas and Epiphany, took place in one day until the middle of the fourth century or in the first two decades of fifth century. Christians though that the day of the death of Christ or of any saint was more significant than his birthday. They avoided celebrating birthdays of saints, including Christ's ${ }^{1}$. The day of the death, the day of the martyrdom became the real birthday of Saints and of Christ because they were led into the kingdom of heaven, in a new heavenly afterlife. Based on this opinion Christ's resurrection was the first important feast for Christians. Then the feast of His Epiphany on $6^{\text {th }}$ of January was more widespread than His birth.

Of course we have some testimonies in patristic texts about the date of the celebration of Christmas as a separate feast but this had to do with specific circumstances and not with something that existed

${ }^{1}$ Joseph F. KeLly underlines that: "This is important for Christmas since some early Christians, especially Origen of Alexandria, objected to birthday celebrations because the Bible mentions only two of them: one for Pharaoh (Genesis 40:20) and one for Herod (Mark 6:21; Matthew 14:6) which both resulted in executions! However, when Christians became interested in Christ's birthday, acceptance of the martyrs" "birthdays" guaranteed that no real opposition would occur". See: Joseph F. KELly, “The Birth of Christmas", Center for Christian Ethics at Baylor University (2011), 11-18, https://www.baylor.edu/content/services/document.php/159119.pdf, esp. 12. Cf. Clement of Alexandria, Stromata I, 21,145.5; Origen of Alexandria, Commentary on Matthew XIV, 6. 
for whole Christian people of the that era. It is accepted according to the writing of Ambrose of Milan that the Church of Rome had separated the feast of Nativity of Christ from His Epiphany in 366 but it is not clear the date of the celebration ${ }^{2}$.

F. C. Conybeare supports that the date $25^{\text {th }}$ December was chosen as an attempt of Christian Fathers to "hallow in the Christian way a day round which more than any other the associations of the older religion centered"3. Pagans celebrated the feast of "Deus Sol Invictus" and it was supported that this feast influenced the date of Christmas. According to this argument, Christmas was celebrated on December 25th in 336, during the time of the Emperor Constantine the Great in order to offset the pagan festival of the Invincible Sun which occurred on that day, as it is referred above. The $25^{\text {th }}$ of December was established by the Church to make a polemic against the pagans' worship of the sun and the stars and to call for the adoration of Christ, the "True Sun of Righteousness", who is Himself worshiped by all of the elements of nature. Also, J.F. Kelly coincides on this opinion ${ }^{5}$.

Cullmann argues and notes that:

${ }^{2}$ Ambrose of Milan, Concerning Virginity, 3.1., trans. by H. de Romestin, E. de Romestin and H.T.F. Duckworth (From Nicene and Post-Nicene Fathers, Second Series, Vol. 10), ed. by Philip Schaff and Henry Wace, Buffalo, NY: Christian Literature Publishing Co., 1896; Revised and edited for New Advent by Kevin Knight, http://www.newadvent.org/fathers/34073.htm.: "For he, when on the Nativity of the Saviour in the Church of St. Peter you signified your profession of virginity by your change of attire (and what day could be better than that on which the Virgin received her child?) while many virgins were standing round and vying with each other for your companionship. You, said he, my daughter, have desired a good espousal. You see how great a crowd has come together for the birthday of your Spouse, and none has gone away without food. This is He, Who, when invited to the marriage feast, changed water into wine".

3 F. C. CONYBeare, "The History of Christmas", in The American Journal of Theology 3 (1) (1899), p. 1-21, în mod special p. 3.

${ }^{4}$ Malachi 4.2, transl. in English by New Revised Standard Version, Anglicised (NRSVA): "But for you who revere my name the sun of righteousness shall rise, with healing in its wings".

5 Joseph F. KELLY, "The Birth of Christmas", p. 15. 
"Our Christmas festival of December 25th was unknown to the Christians of the first three centuries. Down to the beginning of the fourth century this day, subsequently to become a central date in the Christian Church, was allowed by the Christians to pass by unhonoured and unsung, without any assembling together for worship, and without Christ's birth being so much as mentioned"6.

The scholars, based in the writing of John Chrysostom ${ }^{7}$, agree that the choice of the date of $25^{\text {th }}$ December for the feast of the Nativity of Christ was chosen because of ecclesiastic reasons. The important thing of this feast is not the date of the celebration of incarnation but the fact of incarnation itself and the birth of Christ.

\section{The Hymns of Matins of the Feast of the Nativity of Christ in the Greek Orthodox Church. Their dogmatic and theological analysis}

In the beginning of the Service of Matins, the apolytikion "the Troparion (Tone 4)" is said: "Your Nativity, O Christ our God, has shone to the world the Light of wisdom! For by it, those who worshipped the stars, were taught by a Star to adore You, the Sun of Righteousness, and to know You, the Orient from on High. O Lord, glory to You".

God with His Birth enlightens all people's mind in the way that everyone can obtain the light of knowledge in order to understand the mystery of the incarnation of Logos. By this way, the psalm finds its real meaning "and in your light we will see light". Besides, John the evangelist underlines that "God is Light and in Him is no Darkness at all"'. So, the birth of Christ brought the light of knowledge of God

\footnotetext{
${ }^{6}$ Oscar Cullman, "The Origin of Christmas", in O. Cullman, The Early Church, A.J.B. Higgens (eds), London: SCM Press, 1956, p. 21-36, aici p. 21.

7 John Chrysostom, To the birthday of our Salvator, Jesus Christ, PG 49, 354, 358-360.

${ }^{8}$ Psalm 35, $10(36,9)$.

${ }^{9} 1 \mathrm{Jn} 1,5$.
} 
which always accompanied communion with God, and this was the end of the absence of knowledge of God, the darkness of human ignorance. In Maximus' the confessor writing, it is said that the knowledge of God is used in relation to the Incarnation. Only God can make himself known, as He does in the person of his Son incarnate among us ${ }^{10}$. The whole nature took part in this divine revelation. For this reason an unusual star became the light to the Wise Men (Magi, Astronomers), in order to be guided into Christ.

Next hymns are three kathismata. In the first Kathisma hymn (tone 4), it is written:

"Come, O faithful! Let us go to see where Christ was born. We shall follow the wise men, kings from the East, and be led by the guiding star to the place where angels sing unceasing praise. Shepherds in the fields offer fitting hymns: "Glory in the highest to Him who today was born" of the Virgin Theotokos "in a cave in Bethlehem of Judah!".

In this hymn, there is a synopsis of the events of the Nativity of Christ as they are narrated by Matthew and Luke in their gospels ${ }^{11}$. In their gospels, there is a reference to the Magi who came from the East, to the shepherds and to angels who praised and worshipped the New Born Child, the incarnate God $^{12}$. Also, we have the characterization of

10 Maximus the Confessor, Two Hundred Chapters on Theology, 2, 24, PG 90, 1136B. $C f$. Eirini ARTEMI, Christos TerezIS, "The mystical theology as a path of man for the divine Knowledge in the writings of Gregory of Nyssa, Dionysius Areopagite, and Maximus the Confessor", in De Medio Aevo 13 (2019), p. 153-176, aici p. 168.

${ }^{11}$ Matt. 2, 1-12. Lk. 2, 1-20.

12 John Chrysostom underlines: "Today, Bethlehem has become like the firmament above, for in that town angels hymning God take the place of the stars and the Sun of righteousness in a marvelous way takes the place of the physical sun. Where God so wills the laws of nature are overcome. And God so willed, it was in His power, and He did save man, for all things are obedient to God. Today, the eternal One becomes what He was not. While still being God, He also became human without ceasing to be divine. This wondrous and ineffable condescension was hymned with a loud voice by all His angels" (JOHN Chrysostom, Homily on the Nativity of Christ, PG 56, 385B). 
the Holy Virgin as "Theotokos". This term for Holy Virgin Mary summarizes the whole theology of Incarnation of Cyril of Alexandria. The bishop of Alexandria, using the term Theotokos, declared the hypostatic union of Godhead and Manhood in one person, Jesus Christ. He was a perfect man with a body (sarx) and a soul (nous), and he was born by the Virgin Mary. It was obvious that Holy Virgin Mary did not give birth to a common man in whom the Word of God dwelt, lest Christ be thought of as a God-bearing man. For all this, the holy Virgin should be called Theotokos ${ }^{13}$.

In the second Kathisma hymn (tone 4), it is written:

"Why do you marvel, O Mary? Why are you amazed at what has come to pass? "I have given birth in time to a timeless son; I cannot explain how He was conceived in me. I have known no man; how then shall I bear a child? Who has ever seen a birth without seed?" When God so wills, as it is written, "The order of nature is overcome". Christ is born of the virgin in Bethlehem of Judah".

In this hymn there are the basic parts of Christological teaching of the Orthodox Church, developed by Athanasius and Cyril of Alexandria. These Fathers' theology of the person of Jesus is widely seen as a vital underpinning of Orthodox Christology. The words of hymn are paraphrases of Athanasius' words in his homily on the Nativity of Christ: "I behold a strange mystery: instead of the sun, the sun of righteousness contained ineffably in the Virgin. Seek not how this is so, for where God wills the order of nature is overcome. It was His will, He had the power to do so, and thus He came down and saved us"14. The eternal Son of God became in time total man and remained total God through the womb of the Holy Virgin Mary. He became similar to us except the original sin and the inclination to the sin

${ }^{13}$ Cyril of AleXAndria, Third letter to Nestorius, PG 77, 112A. Cf. Eirini Artemi, "Cyril of Alexandria's critique of the term Theotokos", in Acta Theologica 2 (2012), p. 13, https://journals.ufs.ac.za/index.php/at/article/view/2435/2376.

14 Athanasius of AleXANDria, Homily on the Nativity of Christ, https://www.oca.org/holy-synod/statements/his-beatitude-metropolitantikhon/nativity-2012 (27 Febr. 2021). 
because He was conceived in the womb of Theotokos with only the grace of the Holy Spirit and without any seed of a man.

In the third Kathisma hymn (tone 4), it is written:

"How can a womb contain Him whom nothing can contain? How can He remain in His father's bosom, yet rest in his mother's arms? It is His good pleasure to accomplish this. Having no flesh, He purposely assumes it for our sake. He who is becomes what He never was. He shares our substance without forsaking His own nature. Desiring to make us citizens of the world on high, Christ, the Onlybegotten of the Father, is born on earth as a man".

In this troparion, the question, which is expressed based on logic, is how the One who is beyond place and time entered a human womb, in the womb of the Virgin Mary. Also, this hymn as the previous one describes very comprehensively the whole Christological problem. God, who is eternal, became the incarnate Christ and he was both fully God and fully man. His divine nature did not alter His human nature, and His humanity did not diminish His divinity. He was born, having two perfect natures, divinity and humanity, from the first second of his conception in the womb of the Holy Virgin Mary. The mystery of the incarnation of Christ is miraculous, in which the harmonious synthesis of the opposites of two different worlds, the visible and the invisible, is achieved. In the incarnation there is the harmonious synthesis of opposites: Christ was incarnate and wanted to receive the whole humanity, for the salvation of man, the "timeless" God came into in human existence for our salvation.

The phrase "desiring to make us citizens of the world on high" reminds us of the words of the Apostle Paul and of John Chrysostom. Specifically, Paul writes in his epistle to Hebrews: "Therefore he had to become like his brothers and sisters[n] in every respect, so that he might be a merciful and faithful high priest in the service of God, to make a sacrifice of atonement for the sins of the people"15. In another

${ }^{15}$ Hebr. 2, 17, transl. in English by New Revised Standard Version, Anglicised (NRSVA). 
sentence of the same epistle Paul underlines that "Since, therefore, the children share flesh and blood, he himself likewise shared the same things, so that through death he might destroy the one who has the power of death, that is, the devil, and free those who all their lives were held in slavery by the fear of death"16. Additionally, John Chrysostom explains that:

"For this cause (he means) He took on Him our flesh, only for Love to man, that He might have mercy upon us. For neither is there any other cause of the economy, but this alone. For He saw us, cast on the ground, perishing, tyrannized over by Death, and He had compassion on us. To make reconciliation, he says, for the sins of the people. That, He might be a merciful and faithful High Priest"17.

In next troparion, it is said: "Today all things are filled with joy, for Christ is born of the Virgin". In this hymn there is the participation of the universe in joy of birth of Christ, who was born by the Virgin. The whole universe did not escape the judgment of the Fall. The original condition of nature, which was perfect, began to degenerate after the Fall. Christ's birth brings life, harmony and reconciliation. Human sin has not only broken humanity's relationship to God; it has also corrupted the natural order so that God's incarnation entails the restoration of creation to what it was intended to be. All things feel joy because of God's birth as human, because as the Apostle Paul writes "the creation itself will be liberated from its bondage to decay and brought into the freedom"18.

In next hymn (Idiomelon), it is said that:

${ }^{16}$ Hebr. 2, 14-15, transl. in English by New Revised Standard Version, Anglicised (NRSVA).

17 John Chrysostom, Homily of Hebrews, 5.2, PG 63, 47B-C. Trans. by Frederic Gardiner, From Nicene and Post-Nicene Fathers, First Series, Vol. 14. Ed. by Philip Schaff, Buffalo, NY: Christian Literature Publishing Co., 1889. Revised and edited for New Advent by Kevin Knight, http://www.newadvent.org/fathers/240205.htm.

18 Rom. 8, 21, transl. in English by New Revised Standard Version, Anglicised (NRSVA). 
"Glory to God in the highest, and on earth, peace! Today Bethlehem receives Him Who reigns forever with the Father. Today angels glorify the newborn babe in hymns worthy of God: "Glory to God in the highest, and on earth peace, good will toward men!".

The hymn starts and finishes with the same phrase from the gospel of Luke: "Glory to God in the highest, and on earth, peace to men of His will"" . With the phrase "Glory to God in the highest" is underlined that the glory of God is the result of His love, to save man from sin and death. The devil threw man and dragged him into sin, hatred, carnage, wars, sorrow, despair and nihilism. Hatred, malice and the deception of lies, were trying to prevail. The birth of Jesus Christ marked the end of the darkness of falsehood and the decay of sin. The Son of God became man and was born to reveal the truth and the light of God and to lift up the sins of all sinful people, in order to set free people. God's love was revealed: "For God so loved the world, which he gave his only begotten Son, that whosoever believes in him should not perish, but have everlasting life" 20 .

Then, the phrase "Peace on Earth" shows God's will and gift which is peace. From the moment Jesus Christ was born as total man on earth, remaining total God, peace came in the world. Christ himself did not just speak of peace, but gave peace: "Peace I leave with you; My peace I give to you; not as the world gives do I give to you" 21 .

Generally, this angelic hymn proclaimed the good will of God to men, "and through him to reconcile to himself all things" 22 and "recapitulate all things in Christ"23, in the Incarnate and the enfleshed Word of God, "For in Him dwells all the fullness of the Godhead

${ }^{19}$ Lk. 2, 14, transl. in English by New Revised Standard Version, Anglicised (NRSVA).

20 Jn 3, 16, transl. in English by New Revised Standard Version, Anglicised (NRSVA).

21 Jn. 14, 27, transl. in English by New Revised Standard Version, Anglicised (NRSVA).

${ }^{22}$ Col. 1, 20, transl. New International Version (NIV).

${ }^{23}$ Eph. 1, 10, transl. in English by New Revised Standard Version, Anglicised (NRSVA). 
bodily" 24 " "and in Christ you have been brought to fullness. He is the head over every power and authority" 25 and "what is the exceeding greatness of His power toward us who believe, according to the working of His mighty power" 26 in the body of Him of the Church in which "He is the head of the body, the church, who is the beginning, the firstborn from the dead, that in all things He may have the preeminence"27.

The verse "Who reigns forever with the Father" shows the coeternity of God Son with God Father. On the other hand, the tense that is used in this hymn is present because the birth of Christ as a real event of the Lord should be in present tense because Christ as God is always present in the Church.

In the Sessional Hymn (tone 8) is written:

"Calling the magi by a star, Heaven brought the first fruits of the Gentiles to You, A babe lying in the manger: They were amazed to see neither scepter nor throne, but only utter poverty. For what is meaner than a cave, what is more humble than swaddling clothes? Yet there shone forth the wealth of Your divinity: glory to You, O Lord!”.

The hymn refers again to the Magi and to the nature. All these bring presents to God. With the word "utter poverty" isn't meant only the place that Christ was born and the clothes that $\mathrm{He}$ wore, but metaphorically this verse reminds us the verse of the Second Epistle to Corinthians: "For you know the generous act of our Lord Jesus Christ, that though he was rich, yet for your sakes he became poor, so that by his poverty you might become rich" 28 .

24 Col. 2, 9, transl. in English by New Revised Standard Version, Anglicised (NRSVA).

25 Col. 2, 10, transl. in English by New Revised Standard Version, Anglicised (NRSVA).

${ }^{26}$ Eph. 1, 19, transl. in English by New Revised Standard Version, Anglicised (NRSVA).

27 Col. 1, 18, transl. in English by New Revised Standard Version, Anglicised (NRSVA).

282 Cor. 8, 9, transl. in English by New Revised Standard Version, Anglicised (NRSVA). 
The next hymn (Kontakion) in the Matins of the day of Christ's Nativity is written by Romanos the Melodist: "Today the Virgin gives birth to the Supersubstantial One, and the earth offers a cave to the unapproachable One! Angels, with shepherds, glorify Him! The wise men journey with the star! Since for our sake the eternal God was born as a little child!"

In this hymn, Romanos the Melodist expresses the theology of the Incarnation of the World into four verses: "the Virgin gives birth", "the transcendent (Supersubstantial) One", "unapproachable One", "Since for our sake the eternal God was born as a little child". There is the summary of the Christology of Cyril of Alexandria. The Second Person of the Trinity is hyperousios (the transcendent One). $\mathrm{He}$ is the unapproachable One and the eternal God. In this hymn, the christological importance of the Virgin birth cannot be underestimated, because Mary's virginity is a sign of her Son's uniqueness. Andrew Plishka based on the theological analysis of Kallistos Ware ${ }^{29}$ about the connection between Virgin Birth and the Uniqueness of Christ explains that this "points out three ways in which this is true. The fact that Jesus had no earthly father points beyond his situation within time and space to his heavenly origin. Christ is within history yet above it, immanent yet transcendent. Secondly, the virginal conception by Mary underscores the divine initiative in the plan of redemption. Finally, Jesus' birth from a virgin mother points to his eternal pre-existence, for a child conceived and born in the usual human manner is a new person. Jesus Christ is not a new person, but the second person of the Trinity, who has "become" something which he was not, who now lives as a human ${ }^{30}$ as well as God"31.

${ }^{29}$ Kallistos WARE, The Orthodox Way, Crestwood, N.Y.: St. Vladimir's Seminary Press, 1980, p. 101.

30 Joseph RATZINGER, Introduction to Christianity, New York: Seabury, 1979, p. 208: "the Christian belief in the divine Sonship of Jesus does not hinge on the fact that he had no human father-that his divinity would not be affected if he were the product of a normal human marriage, This is because his Sonship is an ontological reality, not a biological one". 
In this hymn, as we referred there is the Christology of Cyril of Alexandria and it encapsulates the Christological message of the feast of the Nativity. The incarnation of the eternal, inapproachable and transcendent Word was the way for the whole human race's salvation $^{32}$. The question is why Romanos used the characterization Virgin instead of Theotokos. We cannot say that there is a specific case, the only thing that we could underline is that with the term "Virgin", Romanos points out that the birth of Christ became without the participation of any man. Mary gave birth but remained a virgin. Through her womb, the Supersubstantial became total man and remained total God. As God rules the Universe but in earth, a cave, a humble place became the place for His birth. This kontakion transfers us in heaven and at the same time on earth. Angles with shepherds say hymns and glorify God and the real Wise Men recognize that something important the heavenly star shows to them. The new born Child is the incarnate eternal God who was born for the salvation of human mankind, "For our sakes, God, Who is before all the ages, is born a little Child". kontakion:

Romanos continues and says in the next part of his

"Bethlehem has opened Eden: come, let us see! We have found joy hidden! Come, let us take possession of the paradise within the cave. There the unwatered stem has appeared, from which forgiveness blossoms forth! There the undug well is found from which David longed to drink of old! There the Virgin has borne a child and at once the thirst of Adam and David is made to cease. Therefore let us hasten to this place where for our sake the Eternal God was born as a little child!".

Through the connection of Eden and Bethlehem Romanos present the birth of Jesus Christ, the enfleshed God as an invitation

${ }^{31}$ Andrew Plishra, Christology and the Marian Kontakia of Saint Romanos the Melodist, Master's theses (Loyola University Chicago, 1983), p. 46 (on-line: https://ecommons.luc.edu/luc_theses/3386).

${ }^{32}$ Cyril of AleXandria, De incarnatione Unigenitii (Sources Chrétiennes 97), 68, p. 131-144 (= PG 75, 1196C-D). 
to any man, who wants in order to re-enter in paradise since the humankind is deified by Christ's participation in human nature ${ }^{33}$. In poetic symbolism the purity of Mary's womb is likened with the inner place of the cave, the unwatered stem, the undug well. By this way Romanos underlines the paradoxical message of the birth of Christ $^{34}$. The significant element is that Romanos doesn't focus on the person of Christ but mainly on the person of the Holy Virgin Mother. She is the one who dominates the context of the hymn.

The next hymn is written by Andrew of Jerusalem, later Andrew of Crete, and has four stanzas:

"Celebrate, $\mathrm{O}$ righteous; rejoice greatly, $\mathrm{O}$ heavens; dance for joy, mountains, for Christ is born; and like a cherubim the Virgin makes a throne, carrying at her bosom God the Word made flesh. Shepherds glorify the new-born Child, Magi offer the Master gifts. Angels sing praises saying: Lord past understanding, glory to You!.

It was the good pleasure of the Father: the Word became flesh, and the Virgin bore God made man. A star spreads abroad the tidings: The Magi worship, the shepherds stand amazed and the creation is filled with the mighty joy!

Virgin Theotokos, you have borne the Savior and have overthrown the curse of Eve. For you have become the mother of Him in Whom the Father was well pleased, and have carried at your bosom God the incarnate Word. We cannot fathom the mystery: but we all glorify it by faith alone, and crying out with you we say: Lord past all understanding, glory to You!

Come, let us sing the praises of the mother of the Savior, who after bearing child still remained virgin. Rejoice, living City of the King in which Christ has dwelt, bringing to pass our salvation. With Gabriel we sing your praises; with the shepherds we glorify you, crying: Theotokos, intercede for our salvation with Him Who took flesh from you!".

\footnotetext{
33 Mary Cunningham, "Eastern Orthodoxy”, ch. 11. in Timothey LARSEN (eds.), The Oxford Handbook of Christmas, in online (October 2020), p. 126-140 (în mod special p. 130).

${ }^{34}$ Ibidem.
} 
In these hymns Andrew of Jerusalem praise the significant role of Theotokos to Christ's incarnation. The title "Theotokos" is used in order to underline to summarize the Christology of Cyril of Alexandria and general the theology of the Church for Theotokos. He ventured to call the holy Virgin Theotokos ${ }^{35}$, not as if the nature of the Word or his divinity had its beginning from the holy Virgin, but because of her was born that holy body with a rational soul, to which the Word, being personally united, is said to be born according to the flesh' ${ }^{36}$. Christ became perfect man and remained perfect God, the two natures being brought together in a true union, there was of both one Christ and one Son; for the difference of the natures was not taken away by the union, but rather the divinity and the humanity make perfect for us the one Lord ${ }^{37}$.

Andrew of Jerusalem/ of Crete refers indirectly to the Holy Virgin Mother as the One who "has overthrown the curse of Eve". Also, he argues that the mystery of Incarnation of Logos cannot be searched by logic but only with the faith. The verse "We cannot fathom the mystery" summarizes the theology of St. Andrew about the supernatural Mystery of the Economy of Salvation that had been hidden from ages and from generations ${ }^{38}$. So the mystery of Incarnation is "supernaturally, beyond logic, beyond any words" 39 . Andrew's hymn refers to the person of the Holy Virgin Mother the Logos more than the other hymns of the matins of Nativity of Christ and continuously underlines that Logos was born of Her, for the sake of the redemption, salvation and deification of humankind ${ }^{40}$.

\footnotetext{
35 ANDREW OF JERUSALEM/ OF CRETE, On the Nativity of the Holy Virgin Mother, 3 , PG 97, 856C.

${ }^{36}$ Cyril of AleXANDria, Epist. 1 Ad Nestorium, PG 77, 45C.

37 E. ARTEMI, "Cyril of Alexandria's critique of the term Theotokos...", p. 1-16. Available from: http://www.scielo.org.za/scielo.php?script=sci_arttext\&pid= S101587582012000200001\&lng=en\&nrm=iso (cited 26/2/2021).

38 Col. 1, 16, transl. in English by New Revised Standard Version, Anglicised (NRSVA).

39 ANDREW OF JERUSALEM/ OF CRETE, On the dormition of the Holy Virgin Mary, 2, 13, PG 97, 1077B. IDEM, On the nativity of the Holy Virgin Mary, 1, PG 97, 808B, 809B.

${ }^{40}$ Ibidem, 1, PG 97, 813D, 814A; IDEM, On the Holy Nativity, 4, PG 97, 864 C.
} 
God is the creator and preserver of the universe, so does the entire universe in heaven and in earth have an active part in the happiness of the glory for Christ's nativity. By their hymns, Andrew, Romanos and the other writers try to show the reconciliation between Man and the Universe through the birth of Christ. According to the Bible, in the beginning the relationship between God and man was harmonious. It was broken as a result of a seemingly innocent temptation, but the consequences of this act have proved to be terrible. Man's attempts to restore harmony remained powerless, thus God himself had to interfere. The task of the incarnate God, Jesus Christ, was to conquer death and to restore man's status in harmony with God - the universe. Therefore the birth of Christ was a necessary condition for the reconciliation between man and God. For this reason, Angels, Magi, Shepherds, stars, animals and the cave worship the Incarnate Christ as an action.

In the following hymn of Germanus, possibly the Bishop of Constantinople in $8^{\text {th }}$ century, the hymnographer says:

"When it was time for Your coming on earth, the first taxation of the world was held; and then You made ready to enroll the names of all who believed in Your birth. For this cause Caesar published such a decree, since Your timeless and eternal Kingdom was newly made manifest. Therefore as we pay our earthly tribute money, we offer You, also, the wealth of our Orthodox faith, O God and Savior of our souls!”.

He means that we orthodox people praise the Lord for the enrichment of Orthodox Theology, coming from the incarnation of the Word of God. And so we can boast of the enrichment of the Theology of the Fathers of the Church, of the Theology of icons, of art, of the general tradition of the Church.

The last hymn, the hymn of John the monk argues that:

"Today Christ is born of the Virgin in Bethlehem! Today He Who knows no beginning begins to be; today is the Word made flesh! The powers of heaven greatly rejoice, and the earth with mankind makes glad. The Magi offer gifts, the shepherds 
proclaim the marvel, and we cry aloud without ceasing: glory to

God in the highest, and on earth peace to men of His will!”.

Once again we see the Church through this Hymn to call the faithful to experience the birth of the Incarnate Logos as a living reality of today. Using the verbs in present tense, the writer of the hymn deletes the boarders of the time and place for the historic event of Christ's birth and enters all of us in the participation of the eternal present of the reconciliation of God with man.

\section{Conclusions}

The portrayal of the Birth of Christ is based on the Bible's witness and on the tradition of the Church, as summarized in the hymn of that day: "On this day, the Virgin begets the hypersubstantial One, and the earth offers up a cavern for the unapproachable One. Angels sing in glorification, together with shepherds. The Magi travel onward, accompanying a star. For our sakes, therefore, a new Child was born: the timeless God". The question that exists in believers' mind is why it is used the present tense for the historic event of the Nativity of Christ which took place once before 2021 and more years ${ }^{41}$ instead of the past tense.

Saint Nicodemus of Mount Athos gives us the answer, emphasizing that orators tend to utter the past in the present tense, to show them as present in the eyes of the listeners and then to make them more spectators than listeners ${ }^{42}$.Time within the Church is relativized, abolished and all the past become present, so that the faithful can take part in experience with his mind, as if they are taking moment at this very moment. The chronicle becomes timeless, eternal

${ }^{41}$ Nobody really knows exactly when Jesus was born. Some scholars think that he was born between 6 B.C. and 4 B.C., based partly on the biblical story of Herod the Great. Cf. John P. MEIER, A Marginal Jew: Rethinking the Historical Jesus, vol. 1 (Anchor Bible Reference Library 1991), p. 373-433.

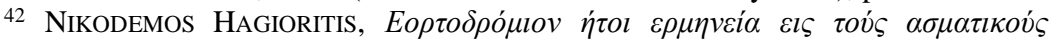

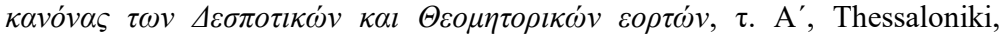
Orthodox Kipseli, 1987, p. 152. 
and idiotic. And not only the past becomes present, but also future. This is strange! How does a future event, which we do not know and has not yet taken place, be present? It is this abolition and relativization of time? The historical event becomes timeless, eternal and idiotic. And not only the past becomes present, but also the future. Also, in the hymns, the person of the Holy Virgin Mother is honored because She is the New Eve. She became the bridge between man and God. In her womb, the mystery of Incarnation took place.

$\cos 80$

\section{Bibliography}

\section{Sources}

1. ANDREW OF JeRUSAlEM/ CReTe, On the dormition of the Holy Virgin Mary, PG 97, 806-1332

2. ANDREW OF JeRUSALEM/ CRETE, On the nativity of the Holy Virgin Mary, 1, PG 97, 808-1332.

3. Ambrose OF Milan, Concerning Virginity, trans. by $\mathrm{H}$. de Romestin, E. de Romestin and H.T.F. Duckworth (From Nicene and Post-Nicene Fathers, Second Series, Vol. 10), ed. by Philip Schaff and Henry Wace, Buffalo, NY, Christian Literature Publishing Co., 1896; Revised and edited for New Advent by Kevin Knight, http://www.newadvent.org/fathers/34073.htm

4. Athanasius of AleXandria, Homily on the Nativity of Christ, https://www.oca.org/holy-synod/statements/his-beatitudemetropolitan-tikhon/nativity-2012

5. Clement of AleXANDria, Stromata, 1-4, Athens 1999.

6. CYrIL OF AleXANDRIA, Third letter to Nestorius, PG 77, 106C-121D.

7. CYRIL OF ALEXANDRIA, De incarnatione Unigenitii (Sources Chrétiennes 97), Paris, Editions du Cerf, 1964 (= PG 75, 1190-1254)

8. John Chrysostom, To the birthday of our Salvator, Jesus Christ, PG 49, 347-362

9. JOHN CHRYSOSTOM, Homily on the Nativity of Christ, PG 56, 385-397. 
10. John Chrysostom, Homily of Hebrews, trans. by Frederic Gardiner (From Nicene and Post-Nicene Fathers, First Series, Vol. 14), Ed. by Philip Schaff, Buffalo, NY, Christian Literature Publishing Co., 1889. Revised and edited for New Advent by Kevin Knight, http://www.newadvent.org/fathers/240205.htm

11. MAXIMUS THE CONFESSOR, Two Hundred Chapters on Theology, PG 90, 1083-1462

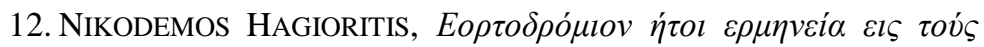

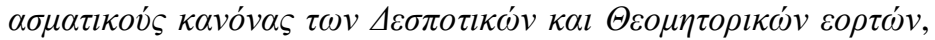
$\tau$. A', (Thessaloniki: Orthodox Kipseli, 1987)

13. ORIGEN OF ALEXANDRIA, Commentary on Matthew.

14. The Hymns of the Matins of the Nativity of Christ, Athens, Apostoliki Diakonia, 2000.

\section{Secondary Bibliography}

15. ARTEMI, E.,"Cyril of Alexandria's critique of the term Theotokos by Nestorius Constantinople", in Acta Theologica, 2 (2012), p. 116. Available from: http://www.scielo.org.za/scielo.php?script= sci_arttext\&pid=S1015-87582012000200001\&lng=en\&nrm=iso [cited 26/2/2021].

16. IDEM/, TEREZIS, Christos "The mystical theology as a path of man for the divine Knowledge in the writings of Gregory of Nyssa, Dionysius Areopagite, and Maximus the Confessor", in De Medio Aevo, 13 (2019), p. 153-176.

17. Conybeare, F. C. "The History of Christmas", in The American Journal of Theology, 3 (1899), p. 1-21.

18. Cullman, Oscar, "The Origin of Christmas", in O. Cullman, The Early Church, A.J.B. Higgens (eds), London, SCM Press, 1956, p. 21-36.

19. CUnNINGHAM, Mary, "Eastern Orthodoxy", in Timothey LARSEN (eds), The Oxford Handbook of Christmas, in online (October 2020), p. 126-140.

20. Kelly, Joseph F. "The Birth of Christmas", Center for Christian Ethics at Baylor University (2011), p. 11-18, https://www.baylor. edu/content/services/document.php/159119.pdf, 
21. MeIER, John P., A Marginal Jew: Rethinking the Historical Jesus, v. 1 (Anchor Bible Reference Library 1991), p. 373-433.

22. PlishKA, Andrew, Christology and the Marian Kontakia of Saint Romanos the Melodist, Master's theses, Loyola University Chicago, 1983, https://ecommons.luc.edu/luc_theses/3386

23. RATZINGER, Joseph, Introduction to Christianity, New York, Seabury, 1979.

24. Ware, Kallistos, The Orthodox Way, Crestwood, N.Y., St. Vladimir's Seminary Press, 1980. 